\title{
Article \\ Chemical Diversity and Antimicrobial Potential of Cultivable Fungi from Deep-Sea Sediments of the Gulf of Mexico
}

\author{
Rodrigo Villanueva-Silva ${ }^{1} \mathbb{D}$, Patricia Velez ${ }^{2}\left(\mathbb{D}\right.$, Meritxell Riquelme $^{3} \mathbb{D}$, Carlos A. Fajardo-Hernández $^{1}(\mathbb{D}$, \\ Anahí Martínez-Cárdenas ${ }^{1}$ D , Alejandra Arista-Romero ${ }^{1}\left(\mathbb{D}\right.$, Baojie Wan ${ }^{4}$, Rui Ma ${ }^{4}$, Mallique Qader ${ }^{4}$, \\ Scott G. Franzblau 4 (D) and Mario Figueroa ${ }^{1, * \mathbb{D}}$
}

1 Facultad de Química, Universidad Nacional Autónoma de México, Ciudad de México 04510, Mexico; code_rodvil@comunidad.unam.mx (R.V.-S.); cfajardo@quimica.unam.mx (C.A.F.-H.); amartinez@quimica.unam.mx (A.M.-C.); aleaar@comunidad.unam.mx (A.A.-R.)

2 Instituto de Biología, Universidad Nacional Autónoma de México, Ciudad de México 04510, Mexico; pvelez@ib.unam.mx

3 Departamento de Microbiología, Centro de Investigación Científica y de Educación Superior de Ensenada (CICESE), Ensenada, Baja California 22860, Mexico; riquelme@cicese.mx

4 Institute for Tuberculosis Research, College of Pharmacy, University of Illinois at Chicago, Chicago, IL 60612, USA; baojie@uic.edu (B.W.); rma20@uic.edu (R.M.); mallique@uic.edu (M.Q.); sgf@uic.edu (S.G.F.)

* Correspondence: mafiguer@unam.mx; Tel.: +52-55-5622-5290

check for updates

Citation: Villanueva-Silva, R.; Velez, P.; Riquelme, M.; Fajardo-Hernández, C.A.; Martínez-Cárdenas, A.; Arista-Romero, A.; Wan, B.; Ma, R.; Qader, M.; Franzblau, S.G.; et al. Chemical Diversity and

Antimicrobial Potential of Cultivable Fungi from Deep-Sea Sediments of the Gulf of Mexico. Molecules 2021, 26, 7328. https://doi.org/10.3390/ molecules 26237328

Academic Editors: Hendrik Luesch and Bryan T. Murphy

Received: 26 October 2021

Accepted: 28 November 2021

Published: 2 December 2021

Publisher's Note: MDPI stays neutral with regard to jurisdictional claims in published maps and institutional affiliations.

Copyright: (c) 2021 by the authors. Licensee MDPI, Basel, Switzerland. This article is an open access article distributed under the terms and conditions of the Creative Commons Attribution (CC BY) license (https:/ / creativecommons.org/licenses/by/ $4.0 /)$.
Abstract: A collection of 29 cultivable fungal strains isolated from deep-sea sediments of the Gulf of Mexico were cultivated under the "one strain, many compounds" approach to explore their chemical diversity and antimicrobial potential. From the 87 extracts tested, over $50 \%$ showed antimicrobial activity, and the most active ones were those from cultures grown at $4{ }^{\circ} \mathrm{C}$ in darkness for 60 days (resembling deep-sea temperature). PCA analysis of the LC-MS data of all the extracts confirmed that culture temperature is the primary factor in the variation of the 4462 metabolite features, accounting for $21.3 \%$ of the variation. The bioactivity-guided and conventional chemical studies of selected fungal strains allowed the identification of several active and specialized metabolites. Finally, metabolomics analysis by GNPS molecular networking and manual dereplication revealed the biosynthetic potential of these species to produce interesting chemistry. This work uncovers the chemical and biological study of marine-derived fungal strains from deep-sea sediments of the Gulf of Mexico.

Keywords: marine fungi; deep-sea sediments; chemical diversity; metabolomics; antimicrobial activity

\section{Introduction}

Microorganisms are the most abundant and diverse living organisms on the planet, contributing to around $60 \%$ of the total of Earth's biomass [1]. Marine microbial diversity plays an important role in the global cycling of nutrients, matter, and energy [2]. Although the number of marine microorganisms is still unknown, especially due to the complications of laboratory cultivation, new methodologies (multi-omics) have emerged to address this question and others related to the different types of organisms, their functional roles, global distribution, and adaptation to varying environmental conditions [2].

Microbes are true master chemists, capable of carrying out the most diverse and complex chemical reactions, and microbial natural products continue to be an important source of new drugs and structural prototypes for the development of new therapeutic agents $[2,3]$.

Endemic fungi and other ubiquitous deep-sea species are adapted to constant darkness, high hydrostatic pressures, microaerophilic conditions, low temperatures $\left(2-4{ }^{\circ} \mathrm{C}\right.$, except for vent systems), low $\mathrm{pH}$, limited nutrients, and the combination of these parameters [4-6]. In addition, it is probable that these microorganisms produce structural molecules such as lipids, enzymes, and biopolymers with unique properties that allow them to thrive under 
extreme conditions [6]. There are about 10,000 species of marine fungi belonging mainly to the Ascomycota and Basidiomycota, estimated in sediments, water columns, driftwood, sessile and mobile invertebrates, algae, and marine mammals [7]. This number is underestimated, as many locations and habitats remain unexplored.

The Gulf of Mexico (GoM) is a large reservoir of scantly studied marine microorganisms [8]. In the last decade, culture-dependent and -independent analyses have been carried out to explore the microbial diversity of the waters and sediments of the GoM. Moreover, the role of these microorganisms in the bioremediation of the ocean is of great importance, e.g., in water and sediments contaminated with mono and polycyclic aromatic hydrocarbons, intermediate chain alkanes, methane, and other gases released during accidental oil spills, mainly by synthesizing enzymes that transforms these products into harmless and less persistent molecules [8-15]. Marine fungi have also shown the ability to produce secondary metabolites that allow them to survive against predators [5]. Finally, the potential ecological participation of these microorganisms as pathogens of animals with commercial importance has been revised [16].

Metagenomic analysis has shown that the GoM contains an unusual fungal diversity compared to marine sediments from other regions in the world. Interestingly, metabolically active fungi have not been studied as deeply as marine bacteria $[8,9,17,18]$. Recently, a series of cultivable fungi from sediments of two oil-drilling deep-sea oil reserves in the GoM were studied for their capacity to grow in media with hexadecane and 1-hexadecene as the only source of carbon [17]. These organisms showed different gene expression profiles. Key hydrocarbonoclastic taxa displayed up-regulated genes involved in transmembrane transport, metabolism of carbohydrates, and nitric oxide pathways. Based on these findings, the GoM represents an important source of fungi with potential for the discovery of active specialized metabolites $[17,19]$.

With this study, we investigated the chemical diversity and antimicrobial potential of 29 cultivable fungi isolated from deep-sea sediments of the GoM. Their extracts obtained from cultures prepared under the "one strain, many compounds" (OSMAC) approach were screened against a set of clinically relevant pathogens. Two active and two inactive species were selected for bioactivity-guided and conventional chemical analysis, respectively. This resulted in the isolation of two benzochromenones, four benzodiazepines, one cytochalasin, and one benzylisoquinoline alkaloid. Additionally, metabolomic analysis by Global Natural Products Social (GNPS) molecular networking and manual dereplication, using the high-resolution mass spectrometry (HRMS-MS/MS) data of their extracts, resulted in the annotation of 15 secondary metabolites. Finally, some of the isolated compounds showed activity against ESKAPE pathogens and tuberculous and non-tuberculous Mycobacteria.

\section{Results and Discussion}

As a part of a program to explore the chemical diversity and antimicrobial potential of fungal species isolated from unexplored areas of Mexico, a series of 29 cultivable fungal strains from marine sediments of the GoM [17] were grown under laboratory conditions. These organisms belong to the genera Penicillium, Cladosporium, Stemphylium, Biatriospora, and Alternaria (Figure 1 and Table 1). Fungi of the Penicillium genus were the most abundant in the samples: P. echinulatum CONTIG4 was obtained from the C14 (Coatzacoalcos) site at a depth of $3240 \mathrm{~m}$, the deepest sampled station. P. brevicompactum CONTIG2 and Penicillium spp. CIGOM5, CIGOM8-CIGOM17, and CIGOM19-CIGOM27 were obtained from the D16 (Coatzacoalcos) site at a depth of $652 \mathrm{~m}$. In addition, Cladosporium sp. CONTIG5, C. halotolerans CIGOM1, and C. ramotenellum CONTIG7 were obtained from the B7 (Perdido), C11 (Coatzacoalcos), and N1 (Perdido) stations at 1191, 860, and $606 \mathrm{~m}$, respectively. Finally, Biatriospora spp. CIGOM2 and CIGOM7 were obtained from the D17 (Coatzacoalcos) station at $976 \mathrm{~m}$, and Alternaria sp. CIGOM4 from N2 (Perdido) at $995 \mathrm{~m}$. All strains were maintained in potato dextrose agar (PDA) medium at room temperature (RT, between $18-22{ }^{\circ} \mathrm{C}$ ) until being used for small- and large-scale cultures. 


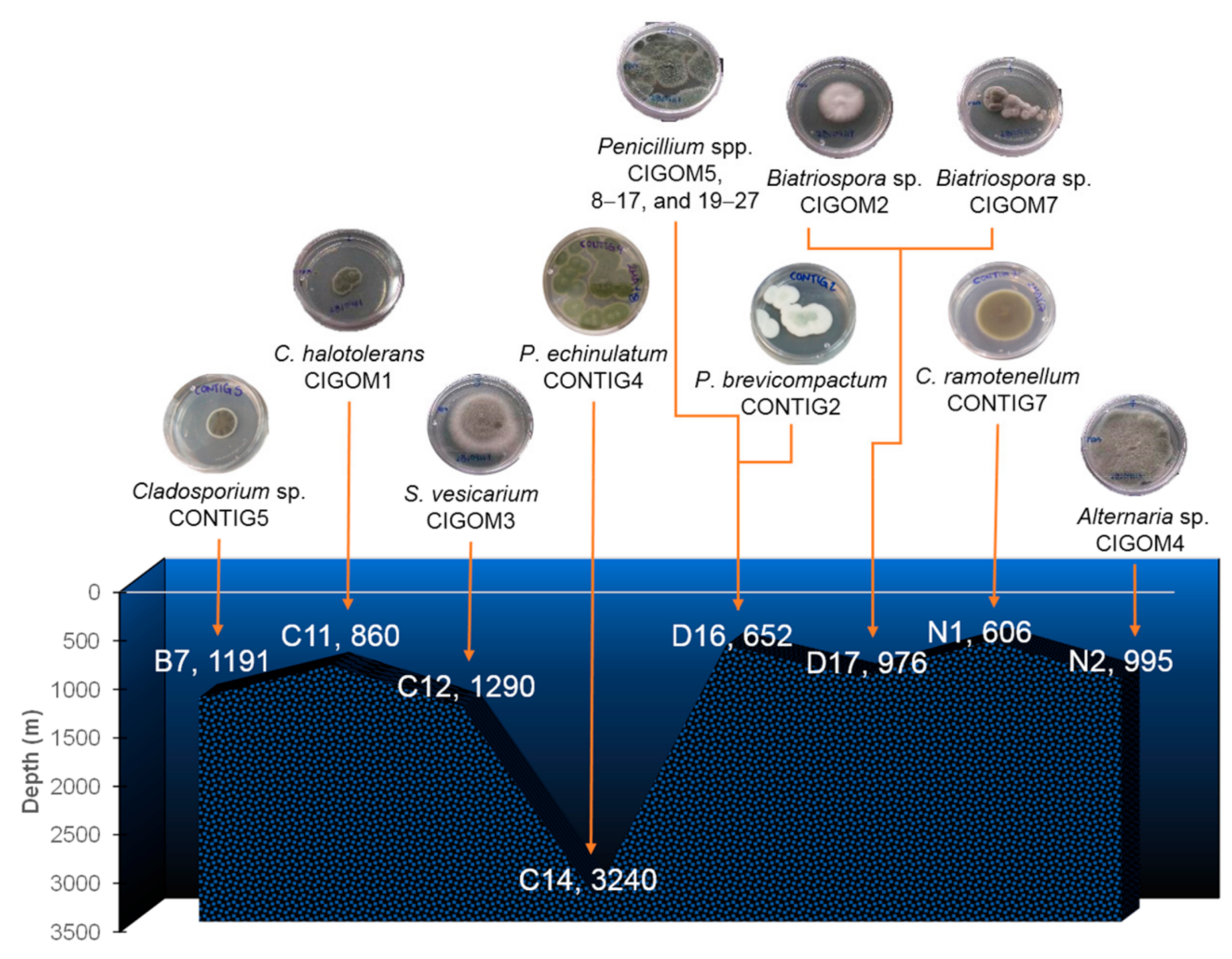

Figure 1. Marine fungi from deep-sea sediments of the GoM.

Table 1. Sampling stations and depths of sediments collection in the GoM.

\begin{tabular}{ccc}
\hline Station & Depth $(\mathbf{m})$ & Strain \\
\hline B7 (Perdido) & 1191 & Cladosporium sp. CONTIG5 \\
C11 (Coatzacoalcos) & 860 & Cladosporium halotolerans CIGOM1 \\
C12 (Coatzacoalcos) & 1290 & Stemphylium vesicarium CIGOM3 \\
C14 (Coatzacoalcos) & 3240 & Penicillium echinulatum CONTIG4 \\
D16 (Coatzacoalcos) & 652 & Penicillium spp. CIGOM5, 8-17, and 19-27 \\
D17 (Coatzacoalcos) & 976 & P. brevicompactum CONTIG2 \\
N1 (Perdido) & 606 & Biatriospora sp. CIGOM2 y CIGOM7 \\
N2 (Perdido) & 995 & Cladosporium ramotenellum CONTIG7 \\
\hline
\end{tabular}

\subsection{Antimicrobial Screening of the Fungal Collection and Effects of Culture Conditions}

In the "one strain, many compounds" (OSMAC) approach, the growth conditions of fungal strains (medium composition, $\mathrm{pH}, \mathrm{O}_{2}$, temperature, etc.) are modified to activate cryptic or silent biosynthetic pathways [20]. Different temperatures (RT, $20^{\circ} \mathrm{C}$, and $4{ }^{\circ} \mathrm{C}$ ) and light/darkness ratios were used for the growth of the 29 strains in rice medium (for details, see Section 3). The defatted $\mathrm{CHCl}_{3}-\mathrm{MeOH}(1: 1)$ extracts of the small-scale cultures were tested against the bacteria Escherichia coli ATCC 10536, Salmonella typhi ATCC 9992V, Pseudomonas aeruginosa ATCC 27853, Staphylococcus aureus ATCC 25923 methicillinsusceptible (MSSA), and Bacillus subtilis ATCC 6633, and the yeast Candida albicans ATCC 10231, at $200 \mu \mathrm{g} / \mathrm{mL}$ and $20 \mu \mathrm{g} / \mathrm{mL}$. From the 87 extracts evaluated, 54 (62\%) showed antimicrobial activity (Table 2 and Table S1). The most active ones (12 extracts) were from cultures grown at $20{ }^{\circ} \mathrm{C}$ in darkness for $30 \mathrm{~d}$ or $4{ }^{\circ} \mathrm{C}$ in darkness for $60 \mathrm{~d}$. Extracts from Alternaria sp. CIGOM4, C. ramotenellum CONTIG7, and P. echinulatum CONTIG4 showed 
the highest antimicrobial potential. Alternaria sp. CIGOM4, cultivated at $4{ }^{\circ} \mathrm{C}$ in darkness for $60 \mathrm{~d}$, completely inhibited B. subtilis at $20 \mu \mathrm{g} / \mathrm{mL}$, the lowest evaluated concentration, and MSSA at $200 \mu \mathrm{g} / \mathrm{mL}$, while the extract obtained from the $20^{\circ} \mathrm{C}$ darkness $30 \mathrm{~d}$ culture, was active against both bacteria at $200 \mu \mathrm{g} / \mathrm{mL}$. Similarly, the extract of P. echinulatum CONTIG4 grown at $20^{\circ} \mathrm{C}$ in darkness for $30 \mathrm{~d}$ showed antimicrobial activity against $E$. coli, S. typhi, and MSSA at $200 \mu \mathrm{g} / \mathrm{mL}$. Finally, C. ramotenellum CONTIG7 showed antimicrobial activity on Gram-positive bacteria when grown at $20{ }^{\circ} \mathrm{C}$ in darkness for $30 \mathrm{~d}$ and at RT with light/darkness $12 / 12 \mathrm{~h}$ for $21 \mathrm{~d}$ (Table 2).

Table 2. Active antimicrobial extracts of marine fungi from the GoM.

\begin{tabular}{|c|c|c|c|c|c|}
\hline Strain & $\begin{array}{c}\text { Extract } \\
\text { Condition }\end{array}$ & $\begin{array}{c}\text { E. coli ATCC } \\
10536\end{array}$ & $\begin{array}{c}\text { S. typhi ATCC } \\
9992 \mathrm{v}\end{array}$ & MSSA & $\begin{array}{c}\text { B. subtilis ATCC } \\
6633\end{array}$ \\
\hline P. echinulatum CONTIG4 & $\mathrm{B}$ & & & & \\
\hline C. ramotenellum CONTIG7 & $\begin{array}{l}\mathrm{A} \\
\mathrm{B}\end{array}$ & & & & \\
\hline S. vesicarium CIGOM3 & $\mathrm{C}$ & & & & \\
\hline Alternaria sp. CIGOM4 & $\begin{array}{l}\mathrm{B} \\
\mathrm{C}\end{array}$ & & & & \\
\hline $\begin{array}{l}\text { Biatriospora sp. CIGOM7 } \\
\text { Penicillium sp. CIGOM16 } \\
\text { Penicillium sp. CIGOM17 } \\
\text { Penicillium sp. CIGOM20 } \\
\text { Penicillium sp. CIGOM21 } \\
\text { Penicillium sp. CIGOM22 } \\
\text { Penicillium sp. CIGOM24 }\end{array}$ & $\begin{array}{l}\text { C } \\
C \\
C \\
C \\
\text { C } \\
\text { C } \\
\text { A }\end{array}$ & & & & \\
\hline Penicillium sp. CIGOM26 & $\begin{array}{l}\mathrm{A} \\
\mathrm{C}\end{array}$ & & & & \\
\hline \multicolumn{6}{|c|}{ Inhibition level } \\
\hline & & $\begin{array}{r}\text { Total inhib } \\
\text { Tot } \\
\text { Partial inhil } \\
\text { Part }\end{array}$ & $\begin{array}{l}\text { at } 200 \mu \mathrm{g} / \mathrm{mL} \text { ar } \\
\text { hibition at } 200 \mu \mathrm{g} \\
\text { at } 200 \mu \mathrm{g} / \mathrm{mL} \text { a } \\
\text { hibition at } 200 \mu \\
\text { No inhibition. }\end{array}$ & $\begin{array}{l}\mathrm{g} / \mathrm{mL} . \\
\mathrm{\mu g} / \mathrm{mL} .\end{array}$ & \\
\hline
\end{tabular}

Rice medium at (A) RT with light/darkness $12 / 12 \mathrm{~h}$ for $21 \mathrm{~d}$; (B) $20^{\circ} \mathrm{C}$ in darkness for $30 \mathrm{~d}$; and (C) $4{ }^{\circ} \mathrm{C}$ in darkness for $60 \mathrm{~d}$.

Interestingly, fungal extracts of a single strain prepared under different growth conditions showed different antimicrobial activity. In marine environments, temperature and light decrease with depth. As observed in Table 2, the antimicrobial activity of the evaluated fungal extracts increased when growth parameters resembled the undersea conditions. To explore the relative impact of the culture conditions in metabolite production, the 87 extracts were subjected to ultra-performance liquid chromatography coupled to photodiode array detection and electrospray ionization tandem high resolution mass spectrometry (UPLC-PDA-HRESIMS-MS/MS) analysis followed by principal component analysis (PCA), using temperature as the determinant variable (Figure 2). 


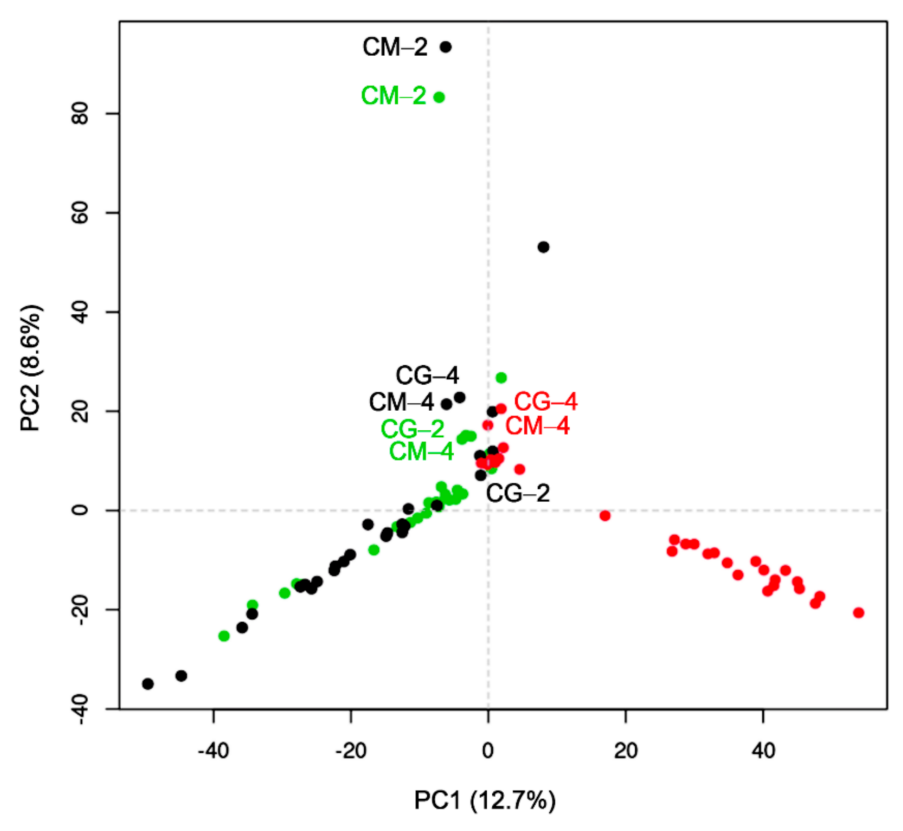

Figure 2. Effect of incubation temperature on the overall metabolites profile determined by PCA analysis of all GoM fungal samples (strains CIGOM (CM) and CONTIG (CG); colors represent growth temperature: red, $4{ }^{\circ} \mathrm{C}$; black, $20^{\circ} \mathrm{C}$; green, RT).

PCA was performed with 4462 metabolite features retained after blank removal (Table S2). Data showed statistically significant clustering depending on the culture temperature, which is a primary factor in the metabolite's profiles and accounts for $21.3 \%$ of the overall chemical variation (Figure 2). Cultures grown at $4{ }^{\circ} \mathrm{C}$ had very slow growth rates, and as expected, metabolites with distinctive features were grouped together (red points) and separated from those obtained from the same strains grown at $20^{\circ} \mathrm{C}$ (black points) and RT (green points; Figure 2). For Biatriospora sp. CIGOM2 (CM-2) cultivated at $20^{\circ} \mathrm{C}$ and $\mathrm{RT}$, there is a grouping separated from the rest of the evaluated species, indicating notable differences in its chemical profile (Figure 2).

For the bioactivity-guided chemical study, scaled-up cultures of two of the most active fungi, Alternaria sp. CIGOM4 and P. echinulatum CONTIG4, were grown at $4{ }^{\circ} \mathrm{C}$ and $20^{\circ} \mathrm{C}$ in darkness for 60 and $30 \mathrm{~d}$, respectively. These strains were also cultivated in rice medium supplemented with a Czapek-Dox solution or artificial marine water to explore their metabolic profile under salty conditions. Salinity is a known abiotic factor that can trigger secondary metabolite production [5]. In addition, to further explore the chemical diversity of the fungal collection in addition to the biological potential, the species Biatriospora sp. CIGOM2 and Penicillium sp. CIGOM10 were subjected to chemical analysis. For all selected species, changes in their main secondary metabolites were established by UPLC-PDA-HRESIMS-MS/MS analysis, and their chemical diversity was explored using the Global Natural Products Social (GNPS) molecular networking platform and manual dereplication analysis [21].

\subsection{Chemical Study of Selected Fungal Strains}

The bioactivity-guided chemical analysis of the scaled-up extracts of Alternaria sp. CIGOM4 and P. echinulatum CONTIG4, and the conventional chemical study of Biatriospora sp. CIGOM2, and Penicllium sp. CIGOM10, yielded eight compounds (Figure 3). Briefly, the extracts were fractionated by flash chromatography using normal-phase columns and a mobile phase composed of $n$-hexane, $\mathrm{CHCl}_{3}, \mathrm{EtOAc}$, and $\mathrm{CH}_{3} \mathrm{OH}$ mixtures. The antimicrobial activity of the fractions was assessed against the same panel of microorganisms (Table S3). Active and some non-active fractions were separated by reverse-phase HPLC (preparative and semipreparative level) on $\mathrm{CH}_{3} \mathrm{CN}-0.1 \%$ aqueous formic acid gradient mobile phase 
(for details, see Section 3). All compounds were characterized by comparison of their spectroscopic (NMR) and spectrometric (HRESIMS-MS/MS) data with those reported in literature (Table S4 and Figures S1-S11, see Supplementary Materials) [22-28].

Benzochromenone alternariol (1) and its methyl-derivative (2) were obtained from Alternaria sp. CIGOM4 antimicrobial fractions, F7 and F4, respectively. The benzodiazepines cyclopenin (3), cyclopeptin (4), and 9,10-dehydrocyclopeptin (5), and the hydroxyquinolone, viridicatin (6) were isolated from the antimicrobial fraction F5 and the inactive fraction F6 of P. echinulatum CONTIG4. Finally, the mycotoxin cytochalasin D (7) and the benzylisoquinoline alkaloid, meleagrin A (8) were isolated from the inactive extracts of Biatriospora sp. CIGOM2 and Penicillium sp. CIOGM10, respectively (Figure 3; for details, see Section 3).

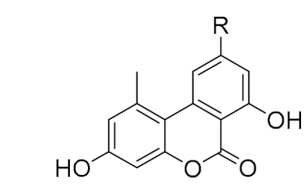

alternariol (1) $\mathrm{R}=\mathrm{OH}$ methyl alternariol (2) $\mathrm{R}=\mathrm{OCH}_{3}$<smiles>O=c1[nH]c2ccccc2c(-c2ccccc2)c1O</smiles>

viridicatin (6)

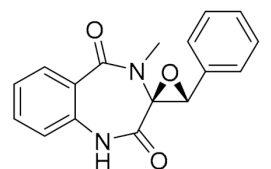

cyclopenin (3)

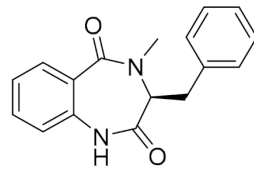

cyclopeptin (4)

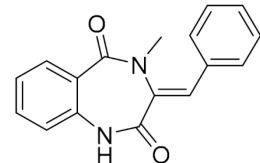

dehydrocyclopeptin (5)

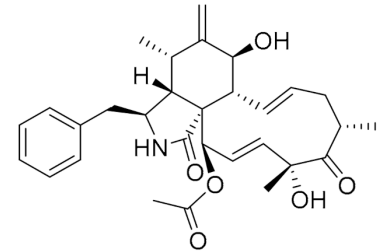

cytochalasin D (7)

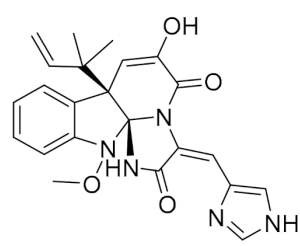

meleagrin $A(\mathbf{8})$

Figure 3. Compounds isolated from strains Alternaria sp. CIGOM4, P. echinulatum CONTIG4, Biatriospora sp. CIGOM2, and Penicllium sp. CIGOM10.

\subsection{Metabolomic Study of Selected GoM Fungal Strains}

To explore the metabolic diversity of the selected fungi Alternaria sp. CIGOM4, P. echinulatum CONTIG4, Biatriospora sp. CIGOM2, and Penicllium sp. CIGOM10, cultivated under different conditions, UPLC-PDA-HRESIMS-MS/MS data of their extracts were subjected to GNPS molecular networking and manual dereplication analysis. First, the molecular network of all four strains displayed 38 clusters containing at least three nodes grouped in four subclasses (Figure 4). From this, 26 non-matching clusters were observed, which probably correlates to the unique chemistry of these strains. Clusters 7 and 4 were annotated as heterocyclic and lipids/lipid-like molecules, respectively; one in the alkaloids and derivatives category; and one in the organic nitrogen compounds category (Figure 4). GNPS automatically annotated compounds (Table 3) were cyclopenin (3) and cyclopeptin (4), isolated from P. echinulatum CONTIG4; cytochalasin D (7), isolated from Biatriospora sp. CIGOM2; and andrastin A (15), a farnesyltransferase inhibitor isolated from several Penicillium species. Furthermore, methyl alternariol (2), meleagrin A (8), tenuazonic acid (10), altersetin (11), cyclopenol (12), viridicatol (13), and roquefortine C (14) were manually dereplicated and annotated by comparison of their UV-absorption maxima and HRMS-MS/MS data against isolated or previously reported compounds, at confidence levels 1 and 2 according to the metabolomics standards initiative and exact mass accuracy $<5$ ppm $[20,29,30]$. 


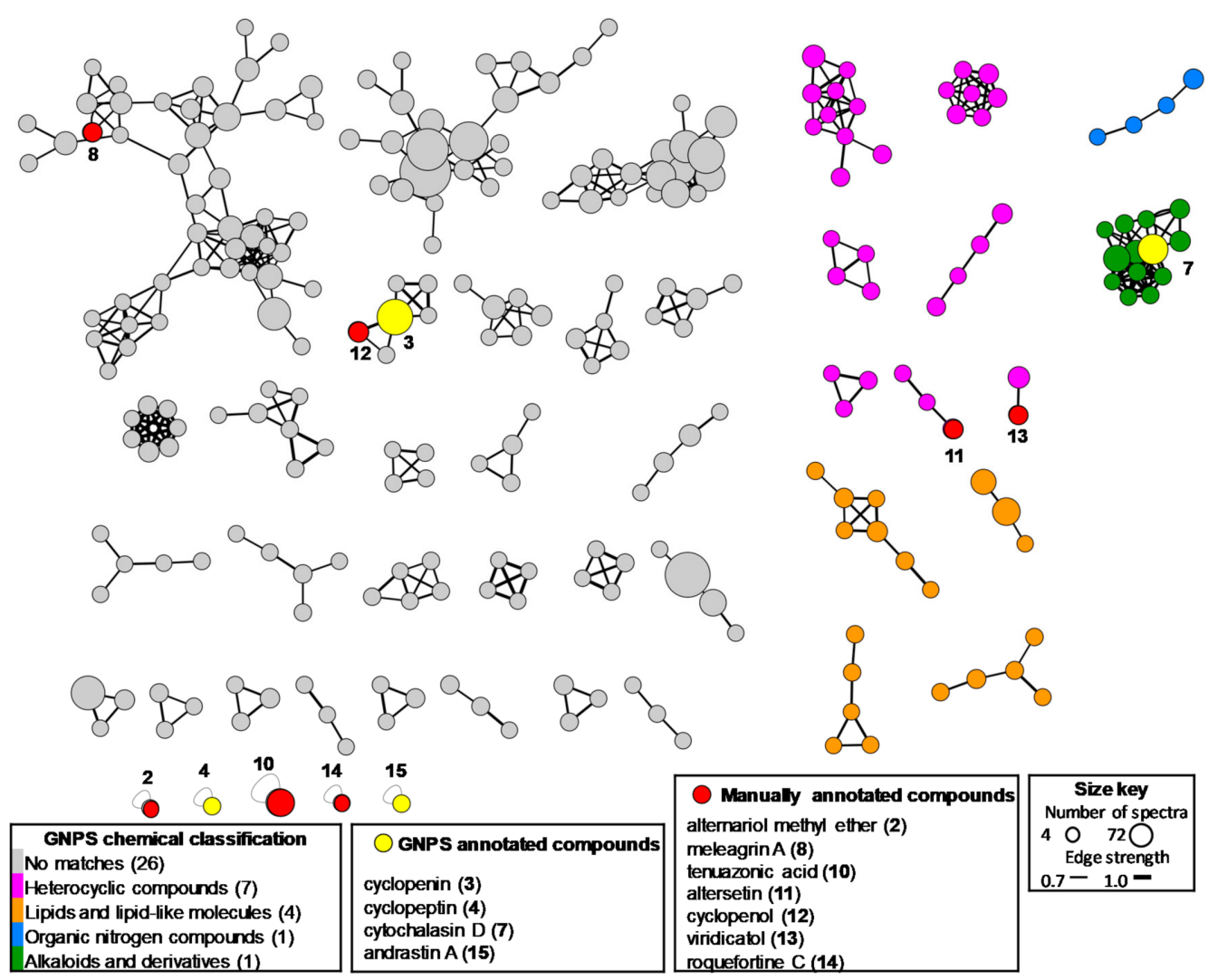

Figure 4. Feature-based GNPS analysis of the metabolites produced by Alternaria sp. CIGOM4, P. echinulatum CONTIG4, Biatriospora sp. CIGOM2 and Penicillium sp. CIGOM10. Edge strength indicates the chemical similarity between MS/MS spectra. Compounds annotated manually and by GNPS are indicated in boxes with arrows pointing to the corresponding node (mass accuracy $<5 \mathrm{ppm}$ ).

Table 3. Chemical annotation by GNPS and by comparison with isolated compounds from selected GoM fungal strains in the molecular networking.

\begin{tabular}{|c|c|c|c|c|c|}
\hline Compound & Adduct & Observed Ion ${ }^{a}$ & Molecular Formula & Exact Mass $^{d}$ & $\begin{array}{c}\text { Mass Accuracy } \\
\text { (ppm) }\end{array}$ \\
\hline Alternariol $(\mathbf{1})$ & {$[\mathrm{M}-\mathrm{H}]^{-}$} & 257.045 & $\mathrm{C}_{14} \mathrm{H}_{10} \mathrm{O}_{5}$ & 257.0452 & -1.3 \\
\hline Alternariol methyl ether (2) & {$[\mathrm{M}+\mathrm{H}]^{+}$} & 273.076 & $\mathrm{C}_{15} \mathrm{H}_{12} \mathrm{O}_{5}$ & 273.0755 & -0.9 \\
\hline Cyclopenin (3) & {$[\mathrm{M}+\mathrm{H}]^{+}$} & 295.108 & $\mathrm{C}_{17} \mathrm{H}_{14} \mathrm{~N}_{2} \mathrm{O}_{3}$ & 295.1074 & -1.10 \\
\hline Cyclopeptin (4) & {$[\mathrm{M}+\mathrm{H}]^{+}$} & 281.128 & $\mathrm{C}_{17} \mathrm{H}_{16} \mathrm{~N}_{2} \mathrm{O}_{2}$ & 281.1282 & -0.9 \\
\hline Dehydrocyclopeptin (5) & {$[\mathrm{M}+\mathrm{H}]^{+}$} & 279.113 & $\mathrm{C}_{17} \mathrm{H}_{14} \mathrm{~N}_{2} \mathrm{O}_{2}$ & 279.1126 & -0.7 \\
\hline Viridicatin (6) & {$[\mathrm{M}+\mathrm{H}]^{+}$} & 238.086 & $\mathrm{C}_{15} \mathrm{H}_{11} \mathrm{NO}_{2}$ & 238.0860 & -1.1 \\
\hline Cytochalasin D (7) & {$[\mathrm{M}+\mathrm{H}]^{+}$} & 508.270 & $\mathrm{C}_{30} \mathrm{H}_{37} \mathrm{NO}_{6}$ & 508.2689 & -0.7 \\
\hline Meleagrin A (8) & {$[\mathrm{M}+\mathrm{H}]^{+}$} & 434.182 & $\mathrm{C}_{23} \mathrm{H}_{23} \mathrm{~N}_{5} \mathrm{O}_{4}$ & 434.1820 & -0.6 \\
\hline Altenuene (9) $\mathrm{b}$ & {$[\mathrm{M}+\mathrm{H}]^{+}$} & 293.102 & $\mathrm{C}_{15} \mathrm{H}_{16} \mathrm{O}_{6}$ & 293.1017 & -0.9 \\
\hline Tenuazonic acid (10) ${ }^{b}$ & {$[\mathrm{M}+\mathrm{H}]^{+}$} & 198.113 & $\mathrm{C}_{10} \mathrm{H}_{15} \mathrm{NO}_{3}$ & 198.1123 & -0.9 \\
\hline Altersetin (11) ${ }^{\mathrm{b}}$ & {$[\mathrm{M}+\mathrm{H}]^{+}$} & 400.248 & $\mathrm{C}_{24} \mathrm{H}_{33} \mathrm{NO}_{4}$ & 400.2479 & -0.8 \\
\hline Cyclopenol (12) ${ }^{b}$ & {$[\mathrm{M}+\mathrm{H}]^{+}$} & 311.102 & $\mathrm{C}_{17} \mathrm{H}_{14} \mathrm{~N}_{2} \mathrm{O}_{4}$ & 311.1023 & -1.1 \\
\hline Viridicatol (13) ${ }^{b}$ & {$[\mathrm{M}+\mathrm{H}]^{+}$} & 254.081 & $\mathrm{C}_{15} \mathrm{H}_{11} \mathrm{NO}_{3}$ & 254.0811 & -0.3 \\
\hline Roquefortine $\mathrm{C}(\mathbf{1 4})^{\mathrm{b}}$ & {$[\mathrm{M}-\mathrm{H}]^{-}$} & 388.178 & $\mathrm{C}_{22} \mathrm{H}_{23} \mathrm{~N}_{5} \mathrm{O}_{2}$ & 388.1781 & +0.5 \\
\hline Andrastin A (15) ${ }^{\mathrm{C}}$ & {$[\mathrm{M}+\mathrm{H}]^{+}$} & 487.269 & $\mathrm{C}_{28} \mathrm{H}_{38} \mathrm{O}_{7}$ & 487.2689 & -3.0 \\
\hline
\end{tabular}

a Values taken from GNPS analysis; ${ }^{\mathrm{b}}$ manually annotated; ${ }^{\mathrm{c}}$ annotated by GNPS; ${ }^{\mathrm{d}}$ data obtained from pure compounds HRMS analysis.

Next, changes in the production of secondary metabolites for the selected fungal strains under the OSMAC cultivation-based approach [31], were assessed by comparison 
with the UPLC-PDA-HRESIMS-MS/MS profiles and by GNPS molecular networking analysis of the extracts obtained from each growth condition.

In the case of Alternaria sp. CIGOM4, the main metabolites alternariol (1) and its methyl ether derivative (2) were observed in all growth conditions (Figure 5). The culture grown at $20^{\circ} \mathrm{C}$ contained the highest concentration of these compounds at a 1:1 ratio. Interestingly, at RT, the fungus produced compound 2 almost exclusively, while at $4{ }^{\circ} \mathrm{C}$, altersetin (11) and $\mathbf{1}$ were the main products. In addition, minor metabolites altenuene (9) and tenuazonic acid (10) were produced in rice medium, but they were not observed when the fungus was grown with artificial sea water or Czapek-Dox media (Figure 5).
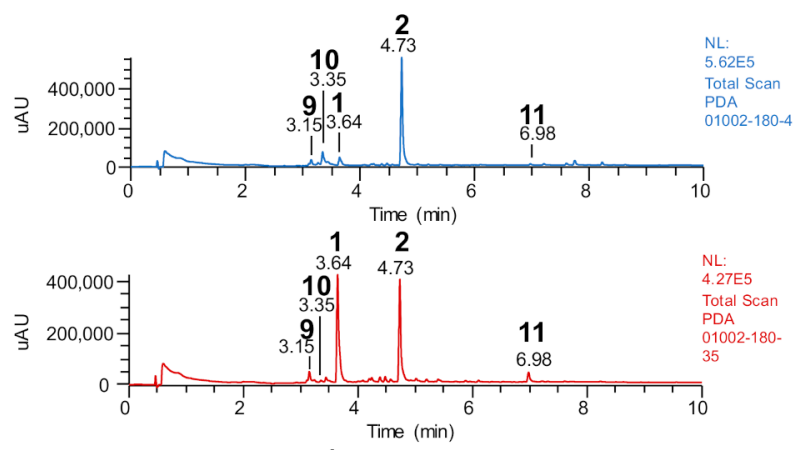<smiles>COc1cc(O)c2c(c1)C1=C(C)[C@H](O)[C@@H](O)C[C@]1(C)OC2=O</smiles>
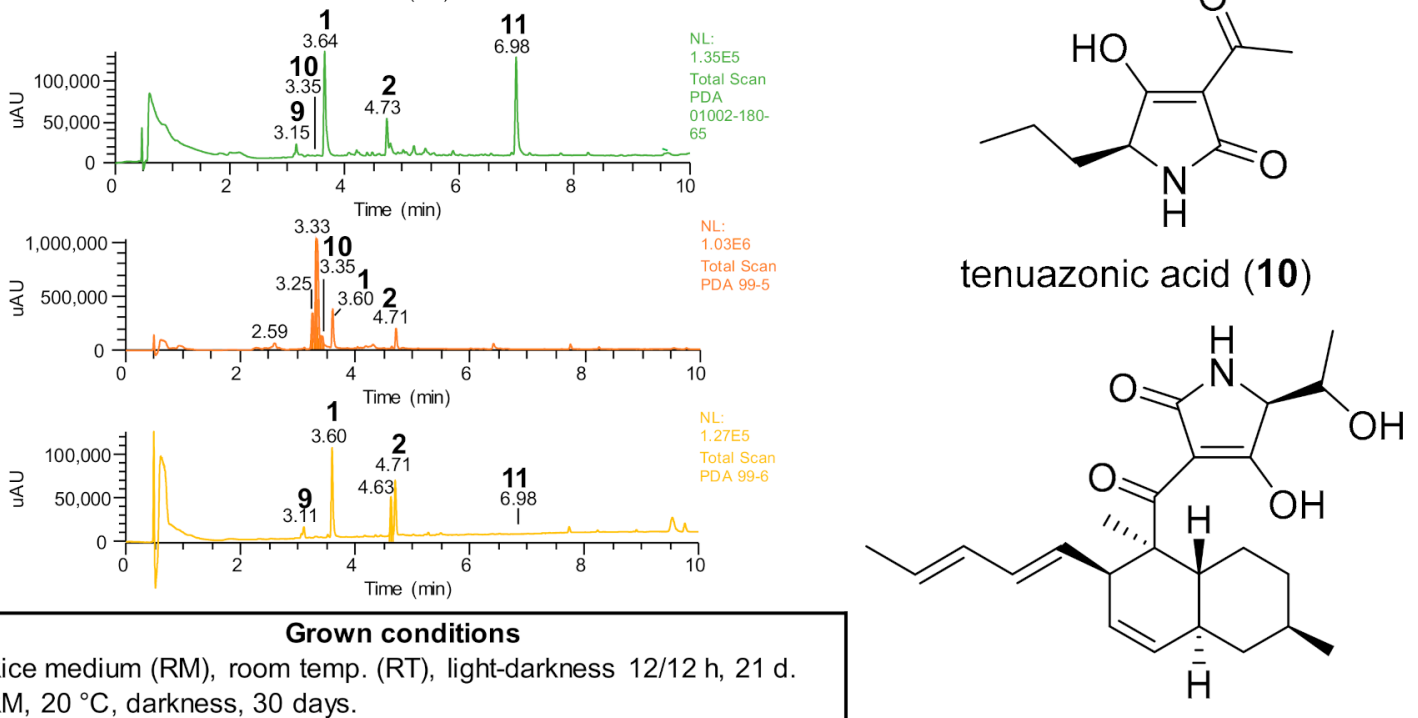

Rice medium (RM), room temp. (RT), light-darkness 12/12 h, $21 \mathrm{~d}$.

$\mathrm{RM}, 20^{\circ} \mathrm{C}$, darkness, 30 days

$\mathrm{RM}, 4{ }^{\circ} \mathrm{C}$, darkness, 60 days.

RM with artificial marine water, RT, light-darkness $12 / 12 \mathrm{~h}, 21 \mathrm{~d}$.

RM with Czapek-Dox broth, RT, light-darkness 12/12 h, 21 d.

altersetin (11)

Figure 5. UPLC-PDA profiles comparison of Alternaria sp. CIGOM4 extracts obtained under different growth conditions (left). Compounds identified by manual dereplication (right).

The strain P. echinulatum CONTIG4 showed notable biosynthetic potential as it produced benzodiazepines 3-5 and the quinolone 6 . In addition to these compounds, manual dereplication of the extracts allowed to identify cyclopenol (12) and viridicatol (13), phenolic derivatives of $\mathbf{3}$ and $\mathbf{6}$, respectively (Figure 6). Comparison of the UPLC-PDA-HRESIMSMS/MS profiles of the extracts revealed that viridicatin (6) was produced at high levels in all conditions, and 9,10-dehydrocyclopeptin (5) was overproduced when the strain was grown at $4{ }^{\circ} \mathrm{C}$ or in salty conditions. Compound 5 was also produced in salty medium, while 3 decreases in these extracts to undetectable levels (Figure 6). GNPS analysis of these extracts grouped all these biological active alkaloids into three clusters, where nodes connected to each other correspond to structurally related compounds (Figure 6). 

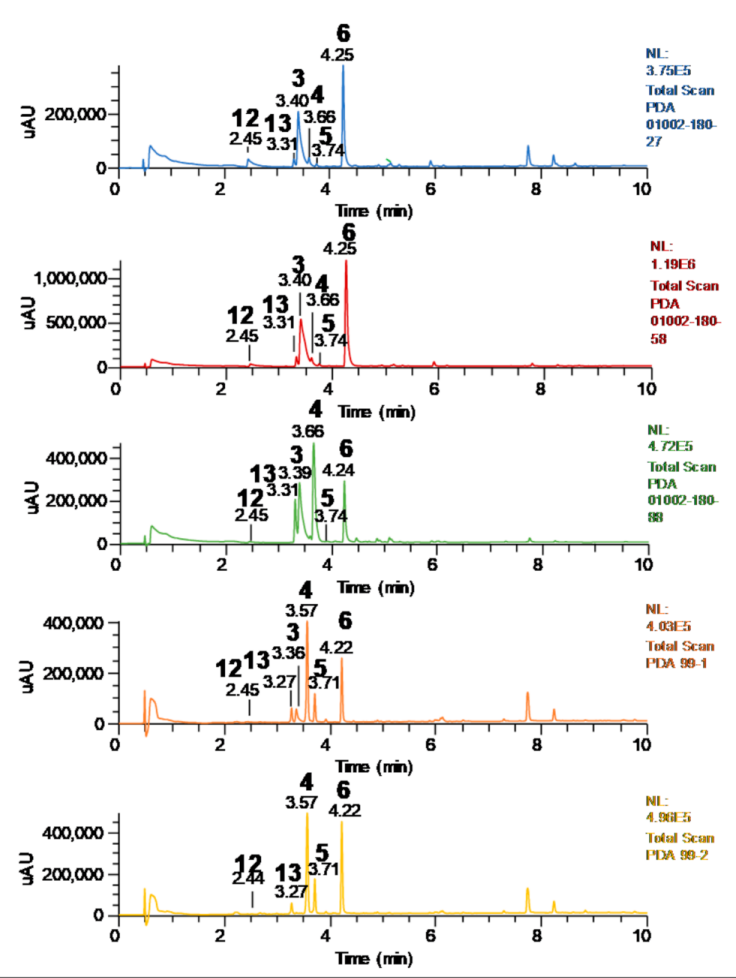

Growth conditions

Rice medium (RM), room temp. (RT), light-darkness 12/12 h, $21 \mathrm{~d}$. $\mathrm{RM}, 20^{\circ} \mathrm{C}$, darkness, $30 \mathrm{~d}$.

$\mathrm{RM}, 4^{\circ} \mathrm{C}$, darkness, $60 \mathrm{~d}$

RM with artificial marine water, RT, light-darkness $12 / 12 \mathrm{~h}, 21 \mathrm{~d}$.

RM with Czapek-Dox broth, RT, light-darkness $12 / 12 \mathrm{~h}, 21 \mathrm{~d}$.

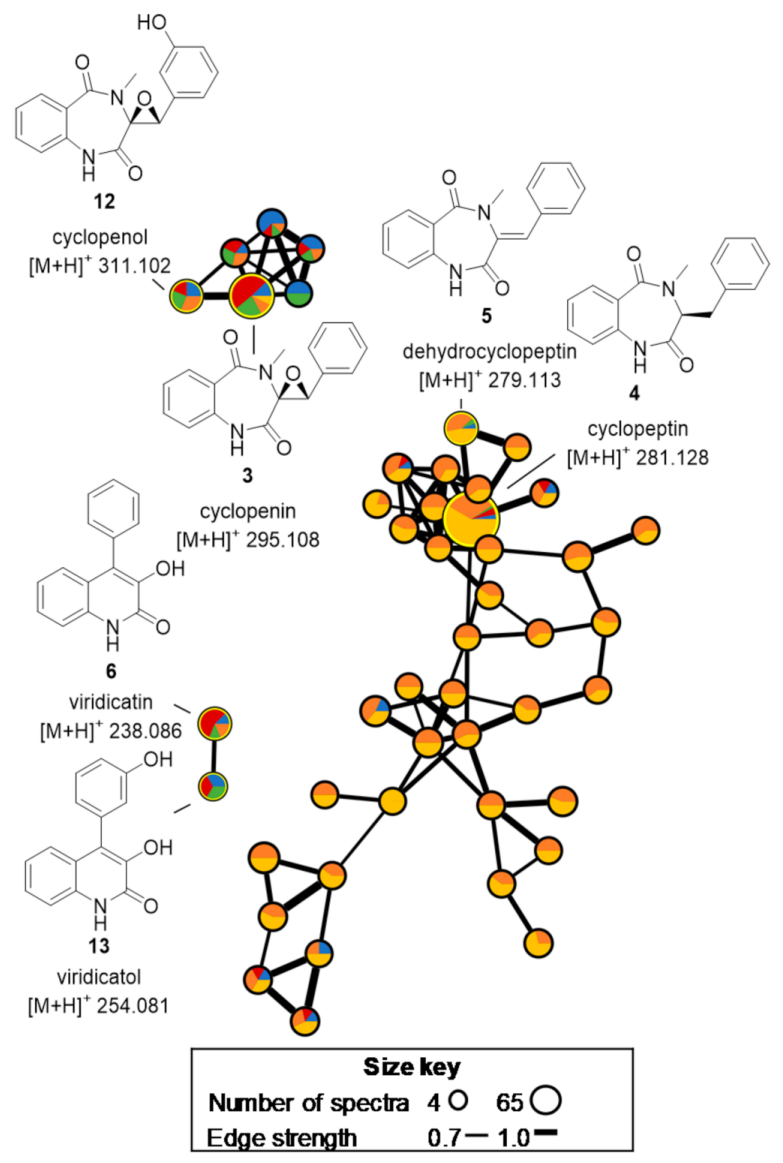

Figure 6. UPLC-PDA profiles comparison and GNPS molecular networking of P. echinulatum CONTIG4 extracts obtained under different growth conditions.

Finally, a comparison of the extracts of Biatriospora sp. CIGOM 2 and Penicillium sp. CIGOM10 obtained under different growth conditions is shown in Figure 7. The strain CIGOM2 yielded the mycotoxin cytochalasin D (7) as its main product; however, when the fungus was grown at $4{ }^{\circ} \mathrm{C}$, this compound was barely produced (Figure 7a). Additionally, peaks observed in the RT and $20^{\circ} \mathrm{C}$ extracts at a retention time $\left(t_{R}\right)$ of $4.77 \mathrm{~min}$ (this peak disappeared fungus was grown at $20^{\circ} \mathrm{C}$ ) and $4.94 \mathrm{~min}$ had the same molecular ion as 7. In the Dictionary of Natural Products, there are nine isomeric cytochalasins derivatives with this weight: cytochalasin C, M and Q, 19,20-epoxy-18-deoxycytochalasin C, 19,20-epoxy-18-deoxycytochalasin $Q$, xylobovatin, chaetoconvosin B, and phomopsichalasin $\mathrm{D}$, that could be correlate to compounds at $\mathrm{t}_{\mathrm{R}} 4.77 \mathrm{~min}$ and $4.94 \mathrm{~min}$. In addition, the GNPS cluster of the annotation of 7, showed all MS/MS fragments reported on the MassBank (record FIO00864; https: / / massbank.eu/MassBank/, accessed on 26 November 2021) for this product (Figure 7a). In the case of Penicillium sp. CIGOM10 (Figure 7b), meleagrin A (8) was the major metabolite in all conditions. By manual dereplication and GNPS annotation, andrastin A (15) was detected only in the RT extract, while roquefortine C (14), a meleagrin A (8) precursor, was detected when the strain was grown at lower temperatures (Figure $7 \mathrm{~b}$ ). 


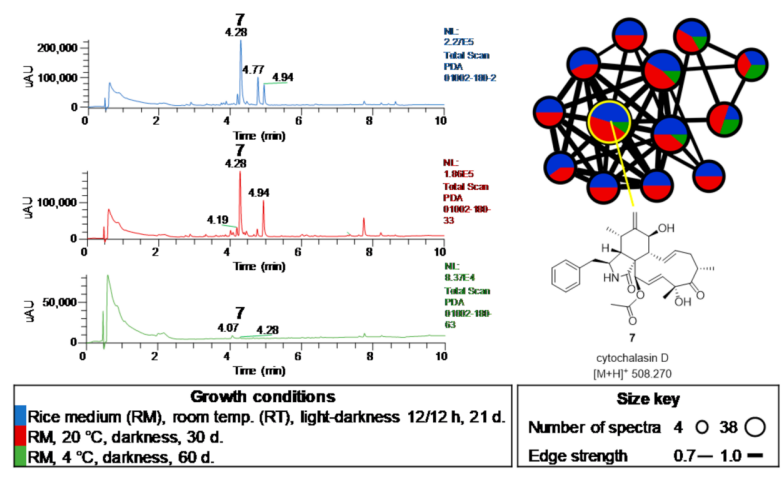

(a)

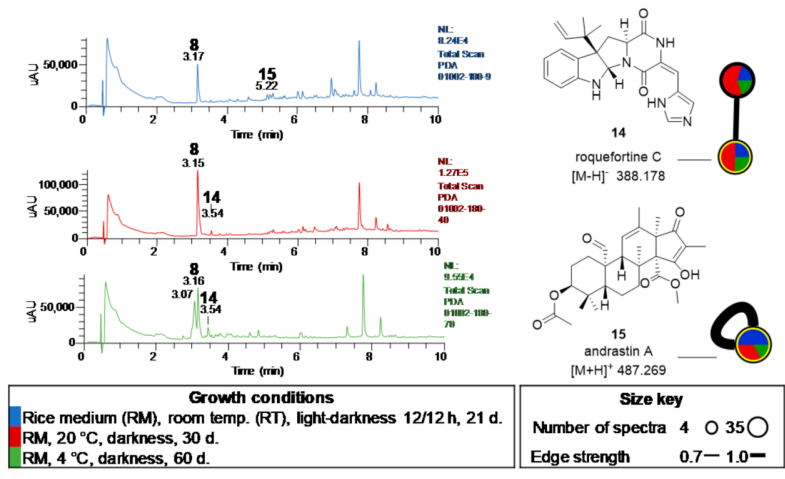

(b)

Figure 7. UPLC-PDA profiles comparison and GNPS molecular networkings of (a) Biatriospora sp. CIGOM 2 (b) and Penicillium sp. CIGOM10 extracts obtained under different growth conditions.

\subsection{Biological Activity of $\mathbf{1}-\mathbf{8}$}

The in vitro antibacterial activity of isolated compounds 1-8 was assessed against a panel of ESKAPE pathogens using the microdilution assay (Table S5) [32], and tuberculous and non-tuberculous Mycobacteria using the microplate Alamar blue (MABA) and low oxygen recovery (LORA) assays (Table S6) [33,34]. Additionally, their cytotoxicity was established against Vero cell lines (Table S6) [35]. From this, only compounds 1, 6, and 8 showed biological activity (Table 4 ).

Table 4. In vitro activity of compounds 1,6 , and 8.

\begin{tabular}{|c|c|c|c|c|c|c|}
\hline \multirow[t]{2}{*}{ Compound } & \multirow[t]{2}{*}{ MSSA } & \multirow[t]{2}{*}{ MRSA } & \multicolumn{2}{|c|}{ M. tuberculosis H37Rv } & \multirow{2}{*}{$\begin{array}{c}\text { M avium } \\
\text { ATCC } 15769\end{array}$} & \multirow{2}{*}{$\begin{array}{c}\text { Vero Cell ATCC } \\
\text { CCL-81 }^{6}\end{array}$} \\
\hline & & & MABA $^{4}$ & LORA $^{5}$ & & \\
\hline Alternariol (1) & & & $87(\mathrm{ND})$ & $>50$ & ND & ND \\
\hline Viridicatin (6) & & & $100(43.8)$ & $>50$ & $>50$ & $>50$ \\
\hline Meleagrin A (8) & & & $101(48.0)$ & $>50$ & 12.3 & $>50$ \\
\hline MIC positive control $(\mu \mathrm{M})$ & $572.41^{1}$ & $0.86^{2}$ & $100(0.03)^{3}$ & $0.08^{3}$ & $0.05^{3}$ & $>100^{3}$ \\
\hline \multicolumn{7}{|c|}{ Inhibition level } \\
\hline & \multicolumn{6}{|c|}{$\begin{array}{c}\text { Total inhibition at } 100 \mu \mathrm{g} / \mathrm{mL} \text { and partial at } 10 \mu \mathrm{g} / \mathrm{mL} \text {. } \\
\text { Total inhibition at } 100 \mu \mathrm{g} / \mathrm{mL} \text {. } \\
\text { Partial inhibition at } 100 \mu \mathrm{g} / \mathrm{mL} \text {. } \\
\text { No inhibition. }\end{array}$} \\
\hline
\end{tabular}

${ }^{1}$ Ampicillin; ${ }^{2}$ Vancomycin; ${ }^{3}$ Rifampicin; ${ }^{4} \%$ Inhibition at $50 \mu \mathrm{g} / \mathrm{mL}(\mathrm{MIC} \mu \mathrm{M}) ;{ }^{5} \mathrm{MIC} \mu \mathrm{M} ;{ }^{6} \mathrm{CC}_{50}$, cytotoxic concentration to $50 \%$ inhibition of the cell line. ND, not determined.

Alternariol (1) showed total inhibition of $S$. aureus methicillin-resistant (MRSA) strain when tested at $387.3 \mu \mathrm{M}$, and it was 10 times more potent $(38.7 \mu \mathrm{M})$ when tested against a methicillin-susceptible strain (Table 4 ). This compound also showed $87 \%$ growth inhibition of $M$. tuberculosis at $50 \mu \mathrm{g} / \mathrm{mL}$. In previous reports, 1 showed important activity against a non-resistant Bacillus subtilis ATCC 6633 with minimum inhibition concentration (MIC) of $33.3 \mu \mathrm{M}$ [36]. Thus, the activity observed in Alternaria sp. CIGOM4 extracts of cultures incubated at $4{ }^{\circ} \mathrm{C}$ and $20{ }^{\circ} \mathrm{C}$ (Table 2) is most likely due to the alternariol (1).

Viridicatin (6) did not show antimicrobial activity against $S$. aureus strains but inhibited the growth of M. tuberculosis with MIC of $43.8 \mu \mathrm{M}$ (Table 2) [37,38]. This compound was inactive against Vero cell lines at the tested concentration (Table 4).

Finally, meleagrin A (8), isolated from CIGOM 10, showed partial inhibition against MSSA at the highest concentration tested (Table 4). In previous studies, this compound demonstrated antibiofilm activity vs. S. aureus ATCC 29213 , with $87.1 \%$ of inhibition at $69.2 \mu \mathrm{M}$ [39]. It also inhibited FabI, an isoform of enoyl-ACP reductase that participates 
in the fatty acid biosynthesis in multidrug-resistant bacteria [40], and antimicrobial activity against different microorganisms in the paper-disk diffusion assay [39]. Lastly, this compound was weakly active against Micrococcus luteus DSMZ 1605 [39]. In our assays, meleagrin A (8) displayed anti-M. tuberculosis and $M$ avium activity with MIC of 48.0 and $12.3 \mu \mathrm{M}$, respectively, and no cytotoxic activity against Vero cell line was observed (Table 4).

\section{Materials and Methods}

\subsection{Strains, Cultures, and Extract Preparations}

Twenty-nine fungal strains were isolated from deep-sea sediment samples collected from eight stations of the GoM during the Metagenomica-Malla Fina cruise (MET-I) and Metagenomics (MET-II) campaigns in 2016 and 2017, respectively, onboard the research vessel Justo Sierra of UNAM (Table 1) $[17,18]$. Each axenic culture in the PDA plates was transferred to ( $1 \%$ of yeast extract, $2 \%$ of soy peptone, $2 \%$ of dextrose) medium and incubated for $5 \mathrm{~d}$ at RT in a shaker at $120 \mathrm{rpm}$. All inoculums were transferred to $250 \mathrm{~mL}$ Erlenmeyer flasks with rice medium $(15 \mathrm{~g} / 30 \mathrm{~mL}$ of deionized water $)$ and maintained under three different conditions: (1) RT with light-darkness $12 / 12 \mathrm{~h}$ for $21 \mathrm{~d}$; (2) $20{ }^{\circ} \mathrm{C}$ in darkness for $30 \mathrm{~d}$; and (3) $4^{\circ} \mathrm{C}$ in darkness for $60 \mathrm{~d}$. After growth, each fungus was extracted with $60 \mathrm{~mL}$ of $1: 1 \mathrm{CH}_{3} \mathrm{OH}-\mathrm{CHCl}_{3}$, shaken on an orbital shaker at $100 \mathrm{rpm}$, and filtered. Then, $60 \mathrm{~mL}$ of $\mathrm{CHCl}_{3}$ and $120 \mathrm{~mL}$ of $\mathrm{H}_{2} \mathrm{O}$ were added to the filtrates and mixed again. The organic layers were separated in a separatory funnel and dried under reduced pressure. The residues were dissolved in $60 \mathrm{~mL}$ of $1: 1 \mathrm{CH}_{3} \mathrm{CN}-\mathrm{CH}_{3} \mathrm{OH}$ and defatted with the same volume of $n$-hexane. Defatted extracts were preserved at room temperature until use [41,42]. Scale-up cultures and extracts of selected strains were prepared using the same methodology as the small-scale cultures but in $150 \mathrm{~g}$ of rice $(300 \mathrm{~mL}$ of deionized water in a $2.8 \mathrm{~L}$ Fernbach flask) and solvent volumes adjusted accordingly. Finally, selected active strains were also grown in rice with Czapek-Dox solution $(100 \mathrm{~g}$ of rice with $200 \mathrm{~mL}$ of Czapek-Dox solution composed of sucrose, $30 \mathrm{~g} / \mathrm{L} ; \mathrm{NaNO}_{3}, 2 \mathrm{~g} / \mathrm{L} ; \mathrm{K}_{2} \mathrm{HPO}_{4}, 1 \mathrm{~g} / \mathrm{L} ; \mathrm{MgSO}_{4}$, $0.5 \mathrm{~g} / \mathrm{L}, \mathrm{KCl}, 0.5 \mathrm{~g} / \mathrm{L}$; and $\mathrm{FeSO}_{4}, 0.01 \mathrm{~g} / \mathrm{L} ; \mathrm{pH} 7.3$ at $25^{\circ} \mathrm{C}$ ) or artificial marine water (32 $\mathrm{g} / \mathrm{L}$ of Instant Ocean Sea Salt) instead of deionized water, in a $2.8 \mathrm{~L}$ Fernbach flask at RT with light-darkness $12 / 12 \mathrm{~h}$ for $21 \mathrm{~d}$ [42].

\subsection{In Vitro Biological Testing}

Defatted extracts, fractions, and pure compounds were tested for antibacterial activity using the broth dilution methods with MTT, following the standard and approved procedures published by the Clinical and Laboratory Standards Institute (CLSI) for microbial testing [32]. DMSO (2.0\%) was used to dissolve all samples. Target bacteria used in the assays (Table 4, Table S1, Table S3 and Table S5) were Bacillus subtilis ATCC 6633, Staphylococcus aureus methicillin-resistant ATCC 43300 (MRSA) and methicillin-susceptible ATCC 25923 (MSSA), Escherichia coli ATCC 10536, Salmonella typhi ATCC 9992V, Pseudomonas aeruginosa ATCC 27853, Enterococcus faecalis vancomycin-resistant ATCC 51299 (VREF) and vancomycin-susceptible ATCC 29212 (VSEF), Klebsiella aerogenes ATCC 13048, Enterobacter cloacae ATCC 700324, Klebsiella pneumoniae ATCC 700603, and Acinetobacter baumannii antibiotic resistant (clinical isolated strain 564) and susceptible ATCC17978, and the yeast Candida albicans ATCC 10231. The bioassays were carried out in 96-well plates in triplicate at concentrations of $200 \mu \mathrm{g} / \mathrm{mL}$ and $20 \mu \mathrm{g} / \mathrm{mL}$ for extracts and fractions, and $100 \mu \mathrm{g} / \mathrm{mL}$ and $10 \mu \mathrm{g} / \mathrm{mL}$ of pure compounds. Pure compounds 1-8 were also tested against $M$. tuberculosis H37Rv strain under both aerobic (replicating) and anaerobic (nonreplicating) conditions using MABA and LORA (Table S6) [33]. Compounds 6 and 8, with activity above $90 \%$ of inhibition of the growth of $M$. tuberculosis in the MABA, were further tested against M. abscessus ATCC 19977, M. chelonae ATCC 35752, M. marinum ATCC 927, M. avium ATCC 15769, and M. kansasii ATCC 12478, using MABA [33,34] and the Vero cell lines ATCC CRL-81 using (3-(4,5-dimethylthiazol-2-yl)-2,5-diphenyltetrazolium bromide (MTT) assay (Table S6) [35]. For the latter assay, $0.6 \mathrm{mM}$ of resazurin was used and the absorbance 
was recorded at $530 \mathrm{~nm}$ (excitation) and $590 \mathrm{~nm}$ (emission). Positive controls for all assays are indicated in each table of results.

\subsection{Chemical Study of Selected Fungal Strains}

The extract (194.0 mg) of Alternaria sp. CIGOM4 was fractionated via flash chromatography on a RediSep RF Gold Si-gel column (4.0 g of Si-gel; Teledyne Inc., Thousand Oaks, CA, USA) using sequential mixtures of $n$-hexane-CHCl3-AcOEt-MeOH. Nine fractions were obtained according to their UV and ELSD profiles. Alternariol (1; $35.5 \mathrm{mg})$ was obtained pure from fraction 7. Fraction 4 was subjected to preparative HPLC (Gemini C18 column $250 \mathrm{~mm} \times 21.2 \mathrm{~mm}$ I.D., $5.0 \mu \mathrm{m}, 100 \AA$ ̊; Phenomenex Inc., Torrance, CA, USA) with a gradient system from $30: 70 \mathrm{CH}_{3} \mathrm{CN}-0.1 \%$ aqueous formic acid to 100 of $\mathrm{CH}_{3} \mathrm{CN}$ in $15 \mathrm{~min}$ at $21.24 \mathrm{~mL} / \mathrm{min}$, yielding $2.8 \mathrm{mg}$ of alternariol $5-O$-methyl ether $\left(2 ; t_{\mathrm{R}}=11.8 \mathrm{~min}\right)$.

From P. echinulatum CONTIG4, extract ( $2.1 \mathrm{~g})$ was fractionated via flash chromatography on a RediSep RF Gold Si-gel column (40 g of Si-gel) using sequential mixtures of $n$-hexane-CHCl3-AcOEt-MeOH. Thirteen primary fractions were obtained according to their UV and ELSD profiles. Fractions $5(174.8 \mathrm{mg}), 6(109.0 \mathrm{mg})$, and $7(43.4 \mathrm{mg})$ were subjected to preparative HPLC (Gemini C18 column $250 \mathrm{~mm} \times 21.2 \mathrm{~mm}$ I.D., $5.0 \mu \mathrm{m}, 100 \AA$ ) with a gradient system from 30:70 $\mathrm{CH}_{3} \mathrm{CN}-0.1 \%$ aqueous formic acid to 100 of $\mathrm{CH}_{3} \mathrm{CN}$ in $15 \mathrm{~min}$ at $21.24 \mathrm{~mL} / \mathrm{min}$, yielding cyclopenin $\left(3 ; 5.5 \mathrm{mg}, t_{\mathrm{R}}=9.197 \mathrm{~min}\right)$, cyclopeptin $\left(4 ; 46.6 \mathrm{mg}, t_{\mathrm{R}}=9.754 \mathrm{~min}\right)$, dehydrocyclopetin $\left(5 ; 6.2 \mathrm{mg}, t_{\mathrm{R}}=10.236 \mathrm{~min}\right)$, and viridicatin $\left(6 ; 14.1 \mathrm{mg}, t_{\mathrm{R}}=12.044 \mathrm{~min}\right)$.

The extract (38.4 g) of Biatriospora sp. CIGOM 2 was fractioned via flash chromatography on a RediSep RF Gold Si-gel column (4 g of Si-gel) using sequential mixtures of $n$-hexane- $\mathrm{CHCl}_{3}-\mathrm{AcOEt}-\mathrm{MeOH}$. Five primary fractions were obtained according to their UV and ELSD profiles. Fraction four was subject to semipreparative HPLC (Gemini C18 column $250 \mathrm{~mm} \times 10.0 \mathrm{~mm}$ I.D., $5.0 \mu \mathrm{m}, 100 \AA$ ) with a gradient system from 15:85 $\mathrm{CH}_{3} \mathrm{CN}-0.1 \%$ aqueous formic acid to 100 of $\mathrm{CH}_{3} \mathrm{CN}$ in $15 \mathrm{~min}$ at $4.72 \mathrm{~mL} / \mathrm{min}$, yielding cytochalasin $\mathrm{D}\left(7 ; 1.7 \mathrm{mg}, t_{\mathrm{R}}=13.95 \mathrm{~min}\right)$.

Finally, the extract $(1.0 \mathrm{~g})$ of Penicillium sp. CIGOM 10 was fractionated via flash chromatography on RediSep RF Gold Si-gel column (40 g of Si-gel) using sequential mixtures of $n$-hexane- $\mathrm{CHCl}_{3}$-AcOEt-MeOH. Twelve fractions were obtained according to their UV and ELSD profiles. Fraction $10(83.6 \mathrm{mg})$ was subject to preparative HPLC (Gemini C18 column $250 \mathrm{~mm} \times 21.2 \mathrm{~mm}$ I.D., $5.0 \mu \mathrm{m}, 100 \AA$ ) with a gradient system from $15: 85 \mathrm{CH}_{3} \mathrm{CN}-0.1 \%$ aqueous formic acid to 100 of $\mathrm{CH}_{3} \mathrm{CN}$ in $15 \mathrm{~min}$ at $21.24 \mathrm{~mL} / \mathrm{min}$, yielding meleagrin $\mathrm{A}\left(\mathbf{8} ; 14.4 \mathrm{mg}, t_{\mathrm{R}}=6.30 \mathrm{~min}\right)$.

\subsection{LC-MS/MS, Untargeted Metabolomic and Molecular Network Analysis}

Extracts $(1 \mathrm{mg} / \mathrm{mL})$, fractions $(1 \mathrm{mg} / \mathrm{mL})$, and pure compounds $(0.1 \mathrm{mg} / \mathrm{mL})$ were analyzed on an Acquity UPLC (Waters Corp., Milford, MA, USA) coupled to a Q Exactive Plus (Thermo Fisher Scientific, Waltham, MA, USA) mass spectrometer. LC analysis was performed on an Acquity BEH C18 column (Waters $50 \mathrm{~mm} \times 2.1 \mathrm{~mm}$ I.D., $1.7 \mu \mathrm{m}, 130 \AA$ ) at $40{ }^{\circ} \mathrm{C}$, with a gradient system from $15: 85 \mathrm{CH}_{3} \mathrm{CN}-0.1 \%$ aqueous formic acid to $100 \%$ of $\mathrm{CH}_{3} \mathrm{CN}$ in $8 \mathrm{~min}$, then held for $1.5 \mathrm{~min}$ with $\mathrm{CH}_{3} \mathrm{CN}$ and returned to the starting conditions, flow rate of $0.3 \mathrm{~mL} / \mathrm{min}$, and injection volume of $3.0 \mu \mathrm{L}$. HRMS-MS/MS data were obtained using an ESI source (positive and negative modes) at a full scan range $(\mathrm{m} / \mathrm{z}$ 150-2000), with the following settings: capillary voltage, $5 \mathrm{~V}$; capillary temperature, $300 \mathrm{C}$; tube lens offset, $35 \mathrm{~V}$; spray voltage, $3.80 \mathrm{kV}$; sheath and auxiliary gas flow, 30 arbitrary units. [30]. Then, MS raw data of all samples were converted to mzXML format using MS Converter of ProteoWizard tool. PCA analysis was performed from the MS data (molecular features after blank removal) using R software (version 4.0.5) with the package FactoMineR [43]. Metabolomic analysis by GNPS molecular networking of all extracts and for the selected fungal strains was assessed using the standard protocol [21] with the following parameters: precursor ion mass tolerance, $0.01 \mathrm{Da}$; fragment ion mass tolerance, $0.02 \mathrm{Da}$; minimum cosine score and score threshold, 0.7 ; minimum matched fragment ions, 
cluster size, and library search minimum matched peaks, 4.0; and maximum connected component size and maximum analog search mass difference, 100. MolNetEnhancer tool was applied for chemical classification [44]. Molecular networks were visualized with Cytoscape 3.8.1 [45]. Finally, manual dereplication was assessed using UV-absorption maxima and HRMS-MS/MS data against MS/MS data of 1-8 and by comparison with those reported in the Dictionary of Natural products [46], SciFinder [47], and an in-house mycotoxins database. The annotation of isolated compounds 1-8 and annotated 9-15 was at confidence level 1 and 2, respectively, according to the metabolomics standards initiative [29] and exact mass accuracy $<5$ ppm.

\subsection{Data Availability}

LC-MS/MS data can be accessed at MassIVE (accession no. MSV000088218; accessed on 26 November 2021). The molecular network of selected fungi can be accessed at http: / / gnps.ucsd.edu/ProteoSAFe/status.jsp?task=1e7a7e47a5c54413a52ef96708565aaf (MolNetEnhancer analysis; accessed on 26 November 2021), molecular network of CONTIG4 at http: / / gnps.ucsd.edu/ProteoSAFe/ status.jsp?task=3b276ea9c0354dd4975472b560e2a6 f7 (accessed on 26 November 2021), molecular network of CIGOM2 at http:/ / gnps.ucsd. edu/ProteoSAFe/status.jsp?task=fd2034712bbd4bb3b72c3edea4e725ef (accessed on 26 November 2021), molecular network of CIGOM10 at http:/ / gnps.ucsd.edu/ProteoSAFe / status.jsp?task=a9a38aed67dc4e69a8caf34d5e1cb2fb (accessed on 26 November 2021).

\section{Conclusions}

This work advances our chemical and biological knowledge of a series cultivable fungal strains isolated from deep-sea sediments of the Gulf of Mexico, an important and poorly studied ecosystem with significant environmental damage as a result of anthropogenic activities. Under the OSMAC approach, the chemical and antimicrobial potential of these strains was exposed. Interestingly, over $50 \%$ of the extracts tested showed antimicrobial activity. The most active were the ones grown under conditions that resemble the deep-sea environment. PCA analysis confirmed that culture temperature is the main factor of chemical variation. The chemical study of selected fungal strains, together with GNPS molecular networking and untargeted metabolomics, allowed the biosynthetic potential of these species to produce interesting chemistry to be discovered. Although several strains did not show biological activity, their potential to produce new chemistry remains to be investigated.

Supplementary Materials: The following are available online, Table S1. Antimicrobial activity of small-scale extracts of marine fungi from the GoM; Table S2. LC-MS data of the 87 fungal extracts used for PCA analysis (features after blank removal); Table S3. Antimicrobial activity of primary fractions of Alternaria sp. CIGOM4 and P. echinulatum CONTIG4 scaled-up extracts; Table S4. Spectroscopic and spectrometric data of isolated compounds; Table S5. Anti-ESKAPE activity of compounds 1-8; Table S6. Anti-Mycobacteria and cytotoxic activities of compounds 1-8; Figure S1. ${ }^{1} \mathrm{H}$ NMR spectrum of alternariol (1) in methanol- $d_{4}(400 \mathrm{MHz})$; Figure S2. ${ }^{1} \mathrm{H}$ NMR spectrum of methyl alternariol (2) in DMSO- $d_{6}\left(400 \mathrm{MHz}\right.$ ); Figure S3. ${ }^{1} \mathrm{H}$ NMR spectrum of cyclopenin (3) in DMSO- $d_{6}$ (400 MHz); Figure S4. ${ }^{13} \mathrm{C}$ NMR spectrum of cyclopenin (3) in DMSO- $d_{6}(100 \mathrm{MHz})$; Figure S5. ${ }^{1} \mathrm{H}$ NMR spectrum of cyclopeptin (4) in $\mathrm{CDCl}_{3}$ (400 MHz); Figure S6. ${ }^{1} \mathrm{H}$ NMR spectrum of dehydrocyclopeptin (5) in $\mathrm{CDCl}_{3}(400 \mathrm{MHz})$; Figure S7. ${ }^{13} \mathrm{C}$ NMR spectrum of dehydrocyclopeptin (5) in $\mathrm{CDCl}_{3}(100 \mathrm{MHz})$; Figure S8. ${ }^{1} \mathrm{H}$ NMR spectrum of viridicatin (6) in methanol- $d_{4}(400 \mathrm{MHz})$; Figure S9. ${ }^{13} \mathrm{C}$ NMR spectrum of viridicatin (6) in methanol- $d_{4}(100 \mathrm{MHz})$; Figure S10. ${ }^{1} \mathrm{H}$ NMR spectrum of cytochalasin $\mathrm{D}$ (7) in $\mathrm{CDCl}_{3}(400 \mathrm{MHz})$; Figure S11. ${ }^{1} \mathrm{H}$ NMR spectrum of meleagrin A (8) in $\mathrm{CDCl}_{3}(400 \mathrm{MHz})$.

Author Contributions: Conceptualization, R.V.-S. and M.F.; methodology, R.V.-S., P.V., M.R., C.A.F.-H., A.M.-C., A.A.-R., B.W., R.M., M.Q., S.G.F. and M.F.; formal analysis, R.V.-S., P.V. and M.F.; writing original draft preparation, review, and editing, R.V.-S., P.V. and M.F. All authors have read and agreed to the published version of the manuscript. 
Funding: This work was supported by grants from UNAM-DGAPA-PAPIIT IN222220 (M.F.) and IN200921 (P.V.), FQ-PAIP 5000-9145 (M.F.), and by the Fondo Sectorial CONACYT-Secretaría de Energía-Hidrocarburos (201441).

Institutional Review Board Statement: Not applicable.

Informed Consent Statement: Not applicable.

Data Availability Statement: The authors confirm that the data supporting the findings of this study are available within the article and its supplementary material.

Acknowledgments: R.V.-S. acknowledges a fellowship from CONACyT (576665) to pursue graduate studies. A.M.-C. acknowledges the postdoctoral fellowship from DGAPA, UNAM. We thank Isabel Rivero-Cruz and the Unidad de Servicios de Apoyo a la Investigación y a la Industria (USAII) from Facultad de Química, UNAM, and to Laura Flores-Bocanegra from the University of North Carolina at Greensboro (UNCG), Greensboro, NC, USA, for their technical support, recording the NMR spectra, and assistance in running UPLC-HRMS.

Conflicts of Interest: The authors declare no conflict of interest. The funders had no role in the design of the study; in the collection, analyses, or interpretation of data; in the writing of the manuscript, or in the decision to publish the results.

Sample Availability: Samples of the compounds 1-8 are available from the corresponding author.

\section{References}

1. Dash, H.R.; Das, S. Chapter 4. Molecular methods for studying microorganisms from atypical environments. In Methods in Microbiology; Gurtler, V., Trevors, J.T., Eds.; Academic Press: Cambridge, MA, USA, 2018; Volume 45, pp. 89-122.

2. Salazar, G.; Sunagawa, S. Marine microbial diversity. Curr. Biol. 2017, 27, R489-R494. [CrossRef] [PubMed]

3. Newman, D.J.; Cragg, G.M. Natural products as sources of new drugs over the nearly four decades from $01 / 1981$ to $09 / 2019$. J. Nat. Prod. 2020, 83, 770-803. [CrossRef] [PubMed]

4. Gladfelter, A.S.; James, T.Y.; Amend, A.S. Marine fungi. Curr. Biol. 2019, 29, R191-R195. [CrossRef] [PubMed]

5. Rédou, V.; Vallet, M.; Meslet-Cladière, L.; Kumar, A.; Pang, K.-L.; Pouchus, Y.-F.; Barbier, G.; Grovel, O.; Bertrand, S.; Prado, S.; et al. Marine Fungi. In The Marine Microbiome: An Untapped Source of Biodiversity and Biotechnological Potential; Stal, L.J., Cretoiu, M.S., Eds.; Springer International Publishing: Cham, Switzerland, 2016; pp. 99-153.

6. Poli, A.; Finore, I.; Romano, I.; Gioiello, A.; Lama, L.; Nicolaus, B. Microbial diversity in extreme marine habitats and their biomolecules. Microorganisms 2017, 5, 25. [CrossRef]

7. Amend, A.; Burgaud, G.; Cunliffe, M.; Edgcomb, V.P.; Ettinger, C.L.; Gutiérrez, M.H.; Heitman, J.; Hom, E.F.Y.; Ianiri, G.; Jones, A.C.; et al. Fungi in the marine environment: Open questions and unsolved problems. mBio 2019, 10, e01189-18. [CrossRef]

8. Vargas-Gastélum, L.; Chong-Robles, J.; Lago-Lestón, A.; Darcy, J.L.; Amend, A.S.; Riquelme, M. Targeted ITS1 sequencing unravels the mycodiversity of deep-sea sediments from the Gulf of Mexico. Environ. Microbiol. 2019, 21, 4046-4061. [CrossRef]

9. Kimes, N.; Callaghan, A.; Aktas, D.; Smith, W.; Sunner, J.; Golding, B.; Drozdowska, M.; Hazen, T.; Suflita, J.; Morris, P. Metagenomic analysis and metabolite profiling of deep-sea sediments from the Gulf of Mexico following the deepwater horizon oil spill. Front. Microbiol. 2013, 4, 50. [CrossRef]

10. King, G.M.; Kostka, J.E.; Hazen, T.C.; Sobecky, P.A. Microbial responses to the Deepwater Horizon oil spill: From coastal wetlands to the deep sea. Ann. Rev. Mar. Sci. 2015, 7, 377-401. [CrossRef]

11. Dombrowski, N.; Donaho, J.A.; Gutierrez, T.; Seitz, K.W.; Teske, A.P.; Baker, B.J. Reconstructing metabolic pathways of hydrocarbon-degrading bacteria from the Deepwater Horizon oil spill. Nat. Microbiol. 2016, 1, 16057. [CrossRef]

12. Bacosa, H.P.; Erdner, D.L.; Rosenheim, B.E.; Shetty, P.; Seitz, K.W.; Baker, B.J.; Liu, Z. Hydrocarbon degradation and response of seafloor sediment bacterial community in the northern Gulf of Mexico to light Louisiana sweet crude oil. ISME J. 2018, 12, 2532-2543. [CrossRef]

13. Noirungsee, N.; Hackbusch, S.; Viamonte, J.; Bubenheim, P.; Liese, A.; Müller, R. Influence of oil, dispersant, and pressure on microbial communities from the Gulf of Mexico. Sci. Rep. 2020, 10, 7079. [CrossRef]

14. Ramírez, D.; Vega-Alvarado, L.; Taboada, B.; Estradas-Romero, A.; Soto, L.; Juárez, K. Bacterial diversity in surface sediments from the continental shelf and slope of the North West Gulf of Mexico and the presence of hydrocarbon degrading bacteria. Mar. Pollut. Bull. 2020, 150, 110590. [CrossRef]

15. Cerqueda-García, D.; García-Maldonado, J.Q.; Aguirre-Macedo, L.; García-Cruz, U. A succession of marine bacterial communities in batch reactor experiments during the degradation of five different petroleum types. Mar. Pollut. Bull. 2020, 150, 110775. [CrossRef]

16. Escobedo-Hinojosa, W.; Pardo-López, L. Analysis of bacterial metagenomes from the Southwestern Gulf of Mexico for pathogens detection. Pathog. Dis. 2017, 75, ftx058. [CrossRef]

17. Velez, P.; Gasca-Pineda, J.; Riquelme, M. Cultivable fungi from deep-sea oil reserves in the Gulf of Mexico: Genetic signatures in response to hydrocarbons. Mar. Environ. Res. 2020, 153, 104816. [CrossRef] 
18. Romero-Hernández, L.; Velez, P.; Betanzo-Gutiérrez, I.; Camacho-López, M.D.; Vázquez-Duhalt, R.; Riquelme, M. Extra-heavy crude oil degradation by Alternaria sp. isolated from deep-sea sediments of the Gulf of Mexico. Appl. Sci. 2021, 11, 6090. [CrossRef]

19. Godoy-Lozano, E.E.; Escobar-Zepeda, A.; Raggi, L.; Merino, E.; Gutierrez-Rios, R.M.; Juarez, K.; Segovia, L.; Licea-Navarro, A.F.; Gracia, A.; Sanchez-Flores, A.; et al. Bacterial diversity and the geochemical landscape in the southwestern Gulf of Mexico. Front. Microbiol. 2018, 9, 2528. [CrossRef]

20. Bode, H.B.; Bethe, B.; Höfs, R.; Zeeck, A. Big effects from small changes: Possible ways to explore nature's chemical diversity. Chembiochem 2002, 3, 619-627. [CrossRef]

21. Wang, M.; Carver, J.J.; Phelan, V.V.; Sanchez, L.M.; Garg, N.; Peng, Y.; Nguyen, D.D.; Watrous, J.; Kapono, C.A.; Luzzatto-Knaan, T.; et al. Sharing and community curation of mass spectrometry data with Global Natural Products Social Molecular Networking. Nat. Biotechnol. 2016, 34, 828-837. [CrossRef]

22. Aly, A.H.; Edrada-Ebel, R.; Indriani, I.D.; Wray, V.; Müller, W.E.; Totzke, F.; Zirrgiebel, U.; Schächtele, C.; Kubbutat, M.H.; Lin, W. Cytotoxic metabolites from the fungal endophyte Alternaria sp. and their subsequent detection in its host plant Polygonum senegalense. J. Nat. Prod. 2008, 71, 972-980. [CrossRef]

23. Tan, N.; Tao, Y.; Pan, J.; Wang, S.; Xu, F.; She, Z.; Lin, Y.; Gareth Jones, E.B. Isolation, structure elucidation, and mutagenicity of four alternariol derivatives produced by the mangrove endophytic fungus No. 2240. Chem. Nat. Compd. 2008, 44, 296-300. [CrossRef]

24. Kusano, M.; Koshino, H.; Uzawa, J.; Fujioka, S.; Kawano, T.; Kimura, Y. Nematicidal alkaloids and related compounds produced by the fungus Penicillium cf. simplicissimum. Biosci. Biotechnol. Biochem. 2000, 64, 2559-2568. [CrossRef]

25. Abdel-Hadi, A.; Awad, M.; Abo-Dahab, N.; El-Shanawany, A.; Abdelkader, M.; Abo-Kadoum, M.V. Viridicatin and dehydrocyclopeptine, two bioactive alkaloids isolated from marine derived fungus Penicillium aurantiogriseum AUMC 9759. IBSPR 2015, 3 , 115-122. [CrossRef]

26. Kishimoto, S.; Hara, K.; Hashimoto, H.; Hirayama, Y.; Champagne, P.A.; Houk, K.N.; Tang, Y.; Watanabe, K. Enzymatic one-step ring contraction for quinolone biosynthesis. Nat. Commun. 2018, 9, 2826. [CrossRef]

27. Jikai, L.; Jianwen, T.; Zejun, D.; Zhihui, D.; Xianghua, W.; Peigui, L. Neoengleromycin, a novel compound from Engleromyces goetzii. Helv. Chim. Acta 2002, 85, 1439-1442. [CrossRef]

28. Kawai, K.; Nozawa, K.; Nakajima, S.; Iitaka, Y. Studies on fungal products. VII. The structures of meleagrin and 9-Opbromobenzoylmeleagrin. Chem. Pharm. Bull. 1984, 32, 94-98. [CrossRef]

29. Sumner, L.W.; Amberg, A.; Barrett, D.; Beale, M.H.; Beger, R.; Daykin, C.A.; Fan, T.W.-M.; Fiehn, O.; Goodacre, R.; Griffin, J.L.; et al. Proposed minimum reporting standards for chemical analysis: Chemical Analysis Working Group (CAWG) Metabolomics Standards Initiative (MSI). Metabolomics 2007, 3, 211-221. [CrossRef]

30. El-Elimat, T.; Figueroa, M.; Ehrmann, B.M.; Cech, N.B.; Pearce, C.J.; Oberlies, N.H. High-resolution MS, MS/MS, and UV database of fungal secondary metabolites as a dereplication protocol for bioactive natural products. J. Nat. Prod. 2013, 76, 1709-1716. [CrossRef]

31. Romano, S.; Jackson, S.A.; Patry, S.; Dobson, A.D.W. Extending the "One Strain Many Compounds" (OSMAC) principle to marine microorganisms. Mar. Drugs 2018, 16, 244. [CrossRef]

32. Balouiri, M.; Sadiki, M.; Ibnsouda, S.K. Methods for in vitro evaluating antimicrobial activity: A review. J. Pharm. Anal. 2016, 6, 71-79. [CrossRef]

33. Cho, S.; Lee, H.S.; Franzblau, S. Microplate Alamar Blue Assay (MABA) and Low Oxygen Recovery Assay (LORA) for Mycobacterium tuberculosis. In Mycobacteria Protocols; Parish, T., Roberts, D.M., Eds.; Springer: New York, NY, USA, 2015; pp. 281-292.

34. Gao, W.; Kim, J.-Y.; Anderson, J.R.; Akopian, T.; Hong, S.; Jin, Y.-Y.; Kandror, O.; Kim, J.-W.; Lee, I.-A.; Lee, S.-Y.; et al. The cyclic peptide ecumicin targeting ClpC1 is active against Mycobacterium tuberculosis in vivo. Antimicrob. Agents Chemother. 2015, 59, 880-889. [CrossRef] [PubMed]

35. Zhou, B.; Shetye, G.; Yu, Y.; Santarsiero, B.D.; Klein, L.L.; Abad-Zapatero, C.; Wolf, N.M.; Cheng, J.; Jin, Y.; Lee, H.; et al. Antimycobacterial rufomycin analogues from Streptomyces atratus strain MJM3502. J. Nat. Prod. 2020, 83, 657-667. [CrossRef] [PubMed]

36. Wang, Y.; Yang, M.-H.; Wang, X.-B.; Li, T.-X.; Kong, L.-Y. Bioactive metabolites from the endophytic fungus Alternaria alternata. Fitoterapia 2014, 99, 153-158. [CrossRef] [PubMed]

37. Zhang, C.-C.; Ding, S.-S.; Shi, W.-S.; Cao, F.; Zhu, H.-J.; Wen, M.-L. A new quinolinone from freshwater lake-derived fungus Myrothecium verrucaria. Nat. Prod. Res. 2017, 31, 99-103. [CrossRef]

38. Cunningham, K.G.; Freeman, G.G. The isolation and some chemical properties of viridicatin, a metabolic product of Penicillium viridicatum Westling. Biochem. J. 1953, 53, 328-332. [CrossRef]

39. Hamed, A.; Abdel-Razek, A.S.; Araby, M.; Abu-Elghait, M.; El-Hosari, D.G.; Frese, M.; Soliman, H.S.; Stammler, H.G.; Sewald, N.; Shaaban, M. Meleagrin from marine fungus Emericella dentata Nq45: Crystal structure and diverse biological activity studies. Nat. Prod. Res. 2021, 35, 3830-3838. [CrossRef]

40. Zheng, C.J.; Sohn, M.-J.; Lee, S.; Kim, W.-G. Meleagrin, a new FabI inhibitor from Penicillium chryosogenum with at least one additional mode of action. PLoS ONE 2013, 8, e78922. [CrossRef] 
41. Aparicio-Cuevas, M.A.; Rivero-Cruz, I.; Sánchez-Castellanos, M.; Menéndez, D.; Raja, H.A.; Joseph-Nathan, P.; González, M.d.C.; Figueroa, M. Dioxomorpholines and derivatives from a marine-facultative Aspergillus species. J. Nat. Prod. 2017, 80, 2311-2318. [CrossRef]

42. VanderMolen, K.M.; Raja, H.A.; El-Elimat, T.; Oberlies, N.H. Evaluation of culture media for the production of secondary metabolites in a natural products screening program. AMB Express 2013, 3, 71. [CrossRef]

43. Lê, S.; Josse, J.; Husson, F. FactoMineR: An R package for multivariate analysis. J. Stat. Softw. 2015, 25, 1-18. [CrossRef]

44. Ernst, M.; Kang, K.B.; Caraballo-Rodríguez, A.M.; Nothias, L.-F.; Wandy, J.; Chen, C.; Wang, M.; Rogers, S.; Medema, M.H.; Dorrestein, P.C.; et al. MolNetEnhancer: Enhanced molecular networks by integrating metabolome mining and annotation tools. Metabolites 2019, 9, 144. [CrossRef]

45. Shannon, P.; Markiel, A.; Ozier, O.; Baliga, N.S.; Wang, J.T.; Ramage, D.; Amin, N.; Schwikowski, B.; Ideker, T. Cytoscape: A software environment for integrated models of biomolecular interaction networks. Genome Res. 2003, 13, 2498-2504. [CrossRef]

46. Dictionary of Natural Products 30.1. Available online: https://dnp.chemnetbase.com/faces/chemical/ChemicalSearch.xhtml (accessed on 26 November 2021).

47. SciFinder-CAS. Available online: https://scifinder.cas.org (accessed on 26 November 2021). 